\title{
Correlation between levels of serum ferritin and lipid profile status.
}

\footnotetext{
1. MBBS, M.Phil (Chemical Pahtology) Assistant Professor Chemical Pathology Khyber Medical College.

2. MBBS, M.Phil (Hematology) Assistant Professor Hematology Khyber Medical College, Peshawar.

3. MBBS

Lecturer Hematology

Khyber Medical College.

4. MBBS, M.Phil (Chemical Pathology)

Assistant Professor Chemical

Pathology

Pakistan Institute of Medical

Sciences Islamabad.
}

Correspondence Address:

Dr. Muhammad Ihtesham Khan Department of Pathology

Khyber Medical College, Peshawar.

ihteshamkhan9@yahoo.com

Article received on:

16/10/2019

Accepted for publication:

06/04/2020
Safia Rahman', Muhammad Ihtesham Khan², Samiyah Rahman ${ }^{3}$, Saman Waqar ${ }^{4}$

ABSTRACT... Objectives: To analyse the correlation between ferritin level in serum and lipid profile in patients presenting to a Tertiary Care Centre. Study Design: Cross Sectional Descriptive study. Setting: Khyber Teaching Hospital Peshawar. Period: $1^{\text {st }}$ January 2019 to 31 ${ }^{\text {st }}$ July 2019. Material \& Methods: About 60 patients presenting to the laboratory referred for serum lipid profile or serum ferritin were included in the study. Sampling was done by purposive non probability technique. Blood was taken from patients in gel tube. Serum ferritin levels and lipid profile were done in all cases. Lipid profile included serum cholesterol, triglyceride level, low density lipoprotein and high density lipoproteins. The levels were recorded in a proforma. The serum ferritin level was correlated with the lipid profile status in all patient and the results were drawn accordingly. Results: About 60 patients were analysed. The mean age was $20.8 \pm$ 5.2 years (range: 2 years to 60 years). There were $39(65 \%)$ males and $21(35 \%)$ females. Out of 60 cases, serum ferritin level was normal, increased and lower in 15(25\%), 40(66.6\%) and $5(8.3 \%)$ cases respectively. The cases where serum ferritin was abnormally raised, the significant changes in lipid profile were raised cholesterol and raised triglyceride (in 62.5\% and $82.5 \%$ cases respectively). Conclusion: There is an association between raised serum ferritin and raised serum cholesterol level and serum triglyceride levels. This supports the link between serum ferritin regulation and lipid metabolism in the body. As dyslipidemia is a major cardiovascular risk factor. Therefore, a raised ferritin level must alert the physician about lipid profile of the patient and should prompt the physician to think about preventive measures against cardiovascular events in order to decrease the morbidity and mortality in patients at risk.

Key words: $\quad$ Lipid Profile, Serum Ferritin, Serum Cholestrol, Tryglycerides.

Article Citation: Rahman S, Khan MI, Rahman S, Waqar S. Correlation between levels of serum ferritin and lipid profile status. Professional Med J 2020; 27(12):26422647. https://doi.org/10.29309/TPMJ/2020.27.12.4254

\section{INTRODUCTION}

Iron is one of the most important macronutrients in body. ${ }^{1}$ It is part of hemoglobin molecule, and also component of cytochrome enzymes in the body. ${ }^{1,2}$ It plays role in transport of oxygen molecules through hemoglobin and synthesis of DNA. ${ }^{1,2}$ It is also involved in a number of metabolic reactions in the body. ${ }^{3,4}$ The iron is stored in the body in hemosiderin and ferritin molecules. ${ }^{1,2}$

Ferritin is a 450 kilo Dalton protein molecule that stores iron in the body. ${ }^{5,6}$ It is also an acute phase protein that plays role in inflammatory process in the body. ${ }^{5}$ Serum ferritin level is measured in clinical practice in certain diseases like iron deficiency anemia, hemochromatosis and thalassemia and in cases where patients are receiving blood transfusions for long periods of time..$^{6,7}$ Although, it is established fact that the iron and ferritin has various important functions in the body. ${ }^{3}$ However, elevated levels of ferritin and iron have deleterious effects on the body. ${ }^{3}$ This is so because elevated ferritin causes formation of free radicals in the cells and impairs the process of lipid peroxidation. ${ }^{3}$ This leads to disruption of cellular processes and cellular dysfunction. ${ }^{3}$ Apart from these effects, the recent research suggests that raised ferritin levels in the body is also associated with metabolic derangements in the body. ${ }^{9}$

Lipids are regarded as an important source of energy in the body. ${ }^{10}$ They have a necessary role in signaling metabolites in body. ${ }^{10}$ It is now an 
established fact that a high level of serum lipids (except the HDL) are the major risk factors for cardiovascular diseases like myocardial infarction and hypertension. ${ }^{6,11}$ Also, an increased level of serum cholesterol leads to oxidative stress in the cells and thus can cause disruption of cellular processes. ${ }^{12}$ A deranged lipid profile status is frequently seen in diabetes mellitus, obesity and hypertension. ${ }^{6}$ Sometimes, in certain hereditary conditions, the lipid profile may be deranged since childhood. ${ }^{9}$ Unluckily, in such cases, it causes premature cardiovascular diseases in young age and is associated with poor prognosis. ${ }^{9}$

The recent research and clinical data proposes that there is a link between regulatory processes of ferritin and lipids in the body. ${ }^{1}$ So, the disruption or abnormality of metabolic pathways of ferritin causes the disruption of that of lipids too. ${ }^{1}$ This relationship between serum ferritin and lipid status may help to predict the risk of the cardiovascular diseases. ${ }^{9}$ Literature also suggests that there is a correlation between the raised serum ferritin levels and dyslipidemia, and hence metabolic syndromes, hypertension and insulin resistance..$^{13}$ It is necessary to maintain a normal serum iron and ferritin levels to avoid the deleterious effects of these molecules on the body. ${ }^{1,14}$ In the same way, serum lipid levels must be maintained to avoid cardiovascular events. ${ }^{1,12}$

No local study has been done in our region to find the correlation between serum ferritin level with lipid profile status. Therefore, we performed the present study with the rationale to determine the correlation between the serum ferritin and serum lipid profile in our setup.

\section{MATERIAL \& METHODS}

It was a Cross sectional descriptive study It was done in Khyber Teaching hospital Peshawar. The study was done from $1^{\text {st }}$ January 2019 to $31^{\text {st }}$ July 2019 (6 months duration). About 60 patients presenting to the laboratory referred for serum lipid profile or serum ferritin were included in the study. Sampling was done by purposive non probability technique. Blood was taken from patients in gel tube. Serum ferritin levels and lipid profile were done on Roche equipment in all cases. Lipid profile included serum cholesterol, triglyceride level, low density lipoprotein and high density lipoproteins. Normal values of serum ferritin was take as $13-150 \mathrm{ng} / \mathrm{ml}$. Normal level for total cholesterol, triglycerides, low density lipoprotein and high density lipoprotein were taken as upto $200 \mathrm{mg} / \mathrm{dl}$, upto $200 \mathrm{mg} / \mathrm{dl}$, $<150 \mathrm{mg} / \mathrm{dl}$, and $30-65 \mathrm{mg} / \mathrm{dl}$ respectively. The levels were recorded in a proforma. The serum ferritin level was correlated with the lipid profile status in all patient and the results were drawn accordingly. Mean and standard deviation were calculated for quantitative variables. Frequency and percentages were used for qualitative variables.

\section{RESULTS}

About 60 cases were included in the study. Age of the study sample ranged from 2 years to 60 years. Mean age was $20.8 \pm 5.2$ years. About 39 (65\%) cases were males. About $21(35 \%)$ cases were females. So, the male to female ratio turned out to be 1.8:1.

The serum ferritin level in study sample is shown in Table-l.

The association of lipid profile with serum ferritin level are shown in Figure-1, 2 and 3.

\begin{tabular}{|l|c|}
\hline \multicolumn{1}{|c|}{ Serum Ferritin } & $\mathbf{n}(\%)$ \\
\hline Normal & $15(25 \%)$ \\
\hline Low & $5(8.3 \%)$ \\
\hline Increased & $40(66.6 \%)$ \\
\hline
\end{tabular}

Table-I. Pattern of serum ferritin level in study sample $(n=60)$

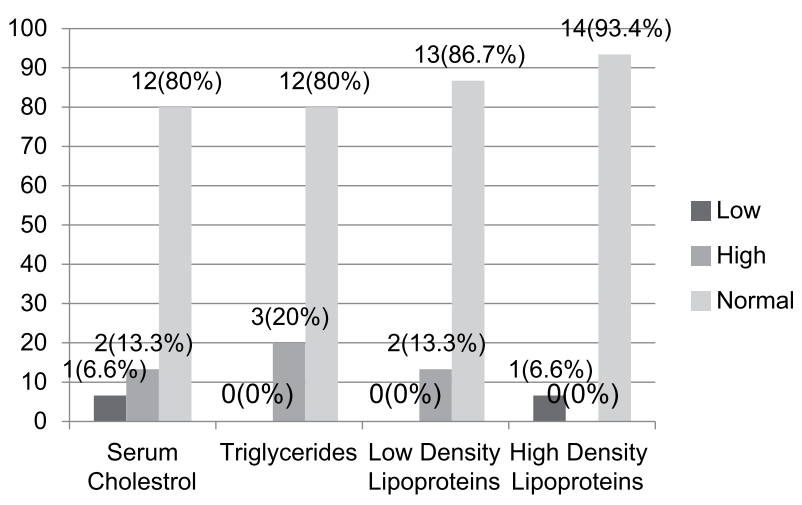

Figure-1. Lipid profile status in cases where serum ferritin was normal $(n=15)$ 


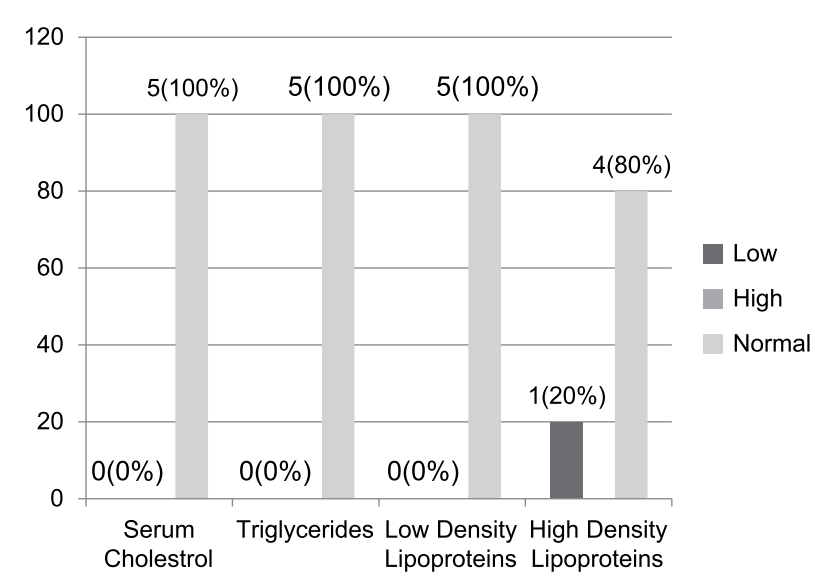

Figure-2. Lipid profile status in cases where serum ferritin was low $(n=5)$

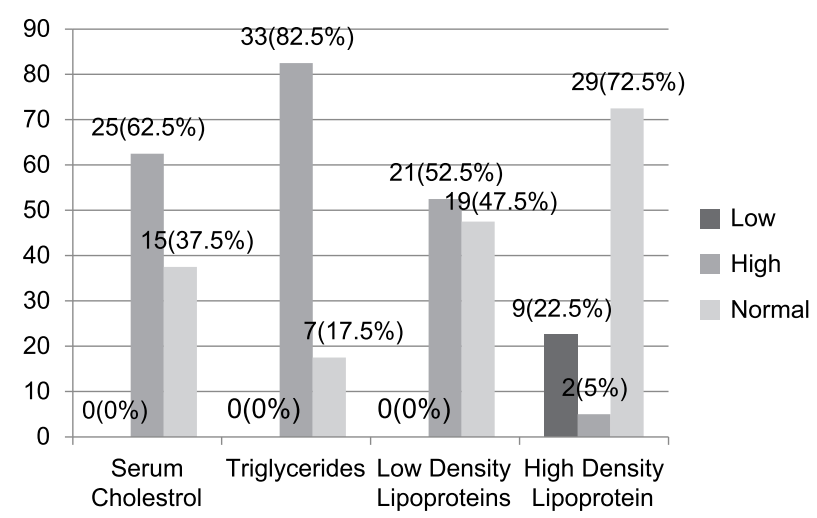

Figure-3. Lipid profile status in cases where serum ferritin was high $(n=40)$

\section{DISCUSSION}

Ferritin is an established storage molecule for body iron stores. ${ }^{9}$ Yet, it has been suggested that excess ferritin is toxic to the cells as it causes formation of the hydroxyl radicals in the cells. ${ }^{15}$ These radicals are hazardous i.e they cause the oxidative stress in the cells and deranges the cell function and structure. ${ }^{15}$ Recent data suggests that there is an association between the regulatory pathways of ferritin and lipid metabolism. ${ }^{1,6}$ The pathways are so much interlinked to each other that derangement of one leads to derangement of the other one. ${ }^{1,6}$ Increase in the level of ferritin causes increased expression of $m$ RNA of several genes that are involved in cholesterol synthesis. ${ }^{1}$ These genes include HMGCR gene (Hydroxy methyl glutaryl CoA reductase), PMVK gene (Phophomevalonate kinase), EBP gene (Emopamil binding protein ) and CYP 51 gene (cytochrome $P$ 450, Family 51) (1,12 $^{1}$ Also, it is suggested that ferritin promotes formation of the lipid droplets in the cells and synthesis of triglyceride in liver cells through mechanisms yet unclear. $^{1}$

In this study, the mean age of the study population was $20.8 \pm 5.2$ years. A male to female ration of 1.8:1 shows male predominance in the present study. In a study done in 2018 in Iraq by Nasif $\mathrm{ZN}$, mean age of the study sample was 47 years, while proportion of the female population was a bit more in that study. ${ }^{5}$ In another study done by Li J from China in 2017, mean age of study population was 50 years with slight female predominance. ${ }^{6}$ Ellidag HY from Turkey suggested mean age of 43 years with slight female predominance. ${ }^{3} \mathrm{Kim}$ YE from Korea reported male predominance which is same as that in our study. ${ }^{9}$ So, the study population was younger in our study as compared to other studies done so far.

In the present study, the serum cholesterol and triglyceride levels were abnormally increased in cases with increased serum ferritn (seen in 62.5\% and $82.5 \%$ cases respectively). However, serum High density lipoproteins levels were normal in cases with raised serum ferritin. This finding is same as that reported in various studies done so far. Ellidag HY from Turkey suggested that raised serum ferritin is associated with raised serum triglycerides and serum cholesterol, while there is no association with high density lipoprotein level. ${ }^{3}$ In another study done by Ledesma $M$ in Spain, it was suggested that raised serum ferritin is strongly associated with raised triglyceride levels. ${ }^{13}$ In another Korean study done by Kim YE in 2016 on 1879 participants, it was found that cases with raised serum ferritin had increased serum cholesterol levels and triglyceride levels but no abnormality in serum high density lipoprotein levels. ${ }^{9}$ This is same as that reported in our study. Kang reported in his study that the increased levels of the ferritin were associated with raised levels of the triglycerides. ${ }^{16}$ Chang in 2013 also suggested that high serum ferritin levels were significantly associated triglyceride levels. ${ }^{17}$ Similar finding are suggested by various studies done so far. $5,18,19,20,21,22,23$ 
Increased levels of the ferritin causes formation of the free radicals, which damages cellular organelles, especially mitochondria. ${ }^{9}$ This impairs $\beta$-oxidation of fatty acids in mitochondria. ${ }^{9}$ This in turn leads to hypertriglyceridemia. ${ }^{9}$ The excess triglycerides accumulate in muscle cells and hepatocytes in the liver and pancreatic cells. ${ }^{9}$ Accumulation in pancreatic beta cells lead to impaired insulin secretion and hence hyperglycemia. ${ }^{9}$ These findings prove the finding that raised serum ferritin has a role in causatioin of metabolic syndrome, central obesity ,diabetes and hypertension. ${ }^{13}$

Salonen was the first researcher to propose the association between high serum ferritin levels and cardiovascular disease. ${ }^{24}$ Salonen suggested that myocardial infarction was twice common in population who had raised serum ferritin as compared to normal population. ${ }^{24}$ After that, further studies were conducted on this aspect which confirmed these findings that raised serum ferritin is associated with cardiovascular diseases. ${ }^{25,26,27,28}$

This study is so far the first one in our region which gives a correlation between levels of the serum ferritin and the lipid profile in our setup.

\section{CONCLUSIONS}

Raised levels of the serum ferritin are associated with raised serum cholesterol level and serum triglyceride levels. There is a link between serum ferritin regulation and lipid metabolism in the body. As dyslipidemia is an established major cardiovascular risk factor. Therefore, a raised ferritin level must alert the physician about checking the lipid profile of the patient and should prompt the physician to think about preventive measures against cardiovascular events. This will decrease the morbidity and mortality in patients at risk

\section{LIMITATIONS}

The present study was done in only single health care centre. So, further studies should be done including patients from various hospitals in order to generate bigger data.

\section{RECOMMENDATIONS}

Finding high serum ferritin in patients must alert the clinician to keep an eye on lipid profile and carry out necessary interventions in order to minimize cardiovascular events in at risk patients.

\section{ACKNOWLEDGEMENT}

All glories be to Almighty Allah for helping me complete the research work.

Copyright $@ 06$ Apr, 2020.

\section{REFERENCES}

1. Rockfield S, Chhabra R, Robertson M, Rehman N, Bisht R, Nanjundan M. Links between iron and lipids: Implications in some major human diseases. Pharmaceuticals. 2018: 11, 113. doi:10.3390/ ph11040113.

2. Abbaspour, N., Hurrell R, Kelishadi R. Review on iron and its importance for human health. J. Res. Med. Sci. 2014, 19: 164-74.

3. Ellidag HY, Eren E, Akdag M, Giray O, Kiraz K, Yilmaz N. The relationship between serum ferritin levels and serum lipids and HDL function with respect to age and gender. Ukr Biochem J. 2016; 88(6):76-86.

4. Wang, J, Pantopoulos, K. Regulation of cellular iron metabolism. Biochem. J. 2011: 434: 365-81.

5. Nasif ZN, Eltayef EM, Janabi NM, Niseaf AN. Relationship of obesity to serum ferritin, Lipid profile, uric acid and urea at Obesity Medical Center in Iraq. Al-Mustan J Sci.2018:18(1):87-96.

6. Li J, Bao W, Zhang T, Zhou Y, Yang H, Jia H, et al. Independent relationship between serum ferritin levels and dyslipidemia in Chinese adults: A population study. PLOS ONE. 2017: 12(12): e0190310.

7. Akter S, Nanri A, Kuwahara K, Matsushita Y, Nakagawa $\mathrm{T}$, Konishi $\mathrm{M}$, et al. Circulating ferritin concentrations and risk of type 2 diabetes in Japanese individuals. J Diab Inv. 2017; 8(4):462-70.

8. Jiang LP, Liang YB, Qiu B, Wang FH, Duan XR, Yang XH, et al. Prevalence of chronic kidney disease in a rural Chinese adult population: The Handan Eye Study. Nep Clinical Prac. 2010; 114(4):c295-c302.

9. Kim YE, Kim DH, Roh YK, Ju SY, Yoon YJ, Nam GE, et al. Relationship between serum ferritin levels and dyslipidemia in Korean adolescents. PLoS One. 2016; 11(4): e0153167

10. Walther TC, Farese RV. Lipid droplets and cellular lipid metabolism. Annu. Rev. Biochem. 2012: 81,687-714. 
11. Parhofer KG. Interaction between glucose and lipid metabolism: More than diabetic dyslipidemia. Diabetes Metab J. 2015; 39(5):353-62.

12. Graham RM., Chua AC, Carter KW, Delima RD, Johnstone D, Herbison CE et al. Hepatic iron loading in mice increases cholesterol biosynthesis. Hepatology. 2010, 52, 462-471.

13. Ledesma M, Roca $\mathrm{YH}$, Leon M, Giraldo P, Pocovi M, Civeira $F$, et al. Association of ferritin elevation and metabolic syndrome in males. Results from the Aragon Workers' Health Study (AWHS). J Clin Endocrinol Metab, 2015, 100(5):2081-89.

14. Wallace D.F. The regulation of iron absorption and homeostasis. Clin. Biochem. Rev. 2016, 37, 51-62.

15. Parola M, Marra F. Adipokines and redox signaling: Impact on fatty liver disease. Antioxid Redox Signal. $2011 ; 15(2): 461-83$.

16. Kang HT, Linton JA, Shim JY. Serum ferritin level is associated with the prevalence of metabolic syndrome in Korean adults: The 2007-2008 Korean National Health and Nutrition Examination Survey. Clin Chim Acta. 2012: 413: 636-41.

17. Chang JS, Lin SM, Huang TC, Chao JC, Chen YC, Pan $\mathrm{WH}$, et al. Serum ferritin and risk of the metabolic syndrome: A population-based study. Asia Pac J Clin Nutr.2013: 22: 400-07. 10.6133/apjcn. 2013.22.3.07.

18. Kunutsor SK, Apekey TA, Walley J, Kain K. Ferritin levels and risk of type 2 diabetes mellitus: An updated systematic review and meta-analysis of prospective evidence. Diabetes Metab Res Rev. 2013; 29(4):308-18.

19. Bao W, Rong Y, Rong S, Liu L. Dietary iron intake, body iron stores, and the risk of type 2 diabetes: A systematic review and meta-analysis. BMC Med. 2012; 10:119.

20. Qing YF, Zhou JG, Zhao MC, Xie WG, Yang QB, Xing $Y$, et al. Altered expression of TPP1 in fibroblast-like synovial cells might be involved in the pathogenesis of rheumatoid arthritis. Rheumat Intl. 2012; 32(8):250310.
21. Jehn ML, Guallar E, Clark JM, Couper D, Duncan $\mathrm{BB}$, Ballantyne $\mathrm{CM}$, et al. A prospective study of plasma ferritin level and incident diabetes: The Atherosclerosis Risk in Communities (ARIC) Study. American J Epidem. 2007; 165(9):1047-54.

22. Kim MK, Chon SJ, Jung YS, Kim BO, Noe EB, Yun BH, et al. Correction: The relationship between serum ferritin levels and insulin resistance in pre and postmenopausal Korean Women: KNHANES 20072010. PLoS One. 2016; 11(7):e0160300.

23. Williams MJ, Poulton R, Williams S. Relationship of serum ferritin with cardiovascular risk factors and inflammation in young men and women. Atherosclerosis. 2002, 165, 179-84.

24. Salonen JT, Nyyssönen K, Korpela H,Tuomilehto J, Seppänen R, Salonen R. High stored iron levels are associated with excess risk of myocardial infarction in eastern Finnish men. Circulation. 1992; 86(3): 80311.

25. Tuomainen TP, Punnonen K, Nyyssönen K, Salonen JT. Association between body iron stores and the risk of acute myocardial infarction in men. Circulation. 1998; 97(15): 1461-6.

26. Vander DL, Grobbee DE, Roest M, Marx JJ, Voorbij HA, Schouw YT. Serum ferritin is a risk factor for stroke in postmenopausal women. Stroke. 2005; 36(8): 163741.

27. Wolff B, Völzke H, Lüdemann J, Robinson D, Vogelgesang $D$, Staudt $A$ et al. Association between high serum ferritin levels and carotid atherosclerosis in the study of health in Pomerania (SHIP). Stroke. 2004; 35(2): 453-7.

28. Li J, Wang R, Luo D, Li S, Xiao C. Association between serum ferritin levels and risk of the metabolic syndrome in Chinese adults: A population study. PLoS One. 2013; 8(9): e74168. 


\begin{tabular}{|c|l|l|l|}
\hline \multicolumn{3}{|c|}{ AUTHORSHIP AND CONTRIBUTION DECLARATION } \\
\hline Sr. \# & \multicolumn{1}{|c|}{ Author(s) Full Name } & \multicolumn{1}{|c|}{ Contribution to the paper } & Author(s) Signature \\
\hline 1 & Safia Rahman & $\begin{array}{l}\text { Main idea, Data collection, } \\
\text { Principle author. } \\
\text { Write up, result compilation. }\end{array}$ \\
\hline 2 & M. Ihtesham Khan & Discussion. \\
\hline 4 & Samiyah Rahman & Saman Waqar & Review, Literature review. \\
\hline
\end{tabular}

